\title{
PEMBUATAN LAPORAN KEUANGAN DAN KREDIT PERBANKAN UNTUK USAHA MIKRO PADA JASA LAUDRY ADI PRATAMA PALEMBANG
}

\author{
M. Nizar al Rasyid, M. Riska Maulana, Yahya \\ Jurusan Adm.Bisnis Polsri e-mail: mnizar@yahoo.com \\ Jurusan Adm.Bisnis Polsri e-mail: muhammadrizka@polsri.ac.id \\ Jurusan Adm.Bisnis Polsri e-mail: yahyaalcaf@yahoo.com
}

\begin{abstract}
This activity is intended to provide counseling in the preparation of financial statements and credit banking aimed at micro business in laundry services Adi Pratama Palembang, from the results of the activity can be concluded that the feasibility of the bank loan scheme is 200 million rupiah with a loan plafond for 36 months up to 60 month, it will be subject to a loan interest rate of $1.50 \%$, of which the installment for 36 months or 3 years is 7,230,479 per month, for 48 months or 4 years installments of 5,875,000 per month and for installments of 60 months or 5 years of 5,078 .685 per month.
\end{abstract}

Keyword: micro busines, the bank loan, credit banking 